\title{
An analysis of a moderate earthquake, eastern flank of the Red Sea, Saudi Arabia
}

\author{
Ali K. Abdelfattah ${ }^{1,2^{*}}$, Abdullah Al-amri', M. Sami Soliman², Faisal K. Zaidi', Saleh Qaysi ${ }^{1}$, Mohamed Fnais ${ }^{1}$, \\ Sattam Almadani ${ }^{1}$ and Nassir Al-Arifi ${ }^{1}$
}

\begin{abstract}
The present study presents the analysis of a moderate earthquake (Mw 4.0) and its largest aftershocks located along the Red Sea coast, southwestern Saudi Arabia, with the aim to understand the enigma of peculiar seismicity in the Arabian Shield. We analyzed a high-quality waveform dataset collected from ten well-recorded earthquakes of moment magnitude ranging from 2.0 to 4.0 in order to determine the hypocenter locations and focal mechanisms. The focal mechanisms were retrieved from the regional moment-tensor inversion for the mainshock and using the P-wave polarities for the corresponding aftershocks of $\mathrm{Mw} \geq 2.0$, respectively. The focal mechanism solutions were inverted to retrieve the seismogenic stress using the stress tensor inversion. The combination of the nearby fault trends and the obtained results from hypocentral relocations, focal mechanism solutions, and stress tensor inversion emphasizes that the NE fault trend is likely to be the causative fault resulting in the 2017 Namas earthquake sequence, implying that the local tectonic setting is incompatible with the large-scale regional tectonics of the Red Sea opening. On the contrary, estimates of low-stress drops exhibit typical values compatible with those reported for the shallow plate-boundary earthquakes that occurred in the Red Sea, suggesting that the existing weak zones in the southernmost part of the Arabian Shield may be attributed to the large-scale regional tectonics of the Red Sea opening.
\end{abstract}

Keywords: Empirical Green's function, Moment-tensor inversion, Small-sized Namas earthquake, Saudi Arabia

\section{Introduction}

In this study, we present results from the analysis of a moderate-sized earthquake ( $\mathrm{Mw}$ 4.0) that occurred in the eastern flank of the Red Sea, Saudi Arabia. The region is not devoid of seismicity and in the recent past small earthquakes $(M<3)$ have occurred. To the south of this area, two prominent earthquakes of $6.2 \mathrm{Mw}$ and 4.4 occurred in 1982 (Yemen) and 2014 (southwestern Saudi Arabia). The preliminary analysis reveals the reactivation of a strike-slip fault, reflecting an incompatible fault-plane solution with large-scale regional tectonics of the Red Sea opening. The Red Sea opening tectonics is consistent with the pull-apart model which assumes that the earliest motion along the Red Sea rift was strike-slip

\footnotetext{
*Correspondence: ali_kamel100@yahoo.co.uk; ali_kamel@yahoo.com

1 Department of Geology \& Geophysics, King Saud University,

Riyadh 11451, Kingdom of Saudi Arabia

Full list of author information is available at the end of the article
}

along reactivated Pan-African sutures and fault zones (Makris and Rihm 1991). Therefore, this study may provide some interesting results to understand the geologi$\mathrm{cal} /$ tectonic processes in the region. The occurrences of peculiar seismicity, in the Arabian Shield, may be attributed either to the stress accumulation transfer from the large-scale regional tectonics of the Red Sea rifting or the stresses driven by the dynamics of the upwelling magma from the Afar mantle plume (Craig et al. 2011; Abdelfattah et al. 2017). Improved knowledge of tectonic processes is the key to understand the stress-strain localization and earthquakes occurring in the Arabian shield, the eastern flank of the Red Sea rifting system, Saudi Arabia.

Since the earthquakes are the only witness of active deformation, the analyses of recent earthquakes recorded by the Saudi Seismic Network (SSN) will provide an understanding of the present-day stress fields that are responsible for the lithospheric deformation in the 
Arabian Shield. Seismic activities that are randomly distributed in the Arabian shield are presumably attributed to the stress transfer due to the relative motion between the African and Arabian shields through the divergent movements acting in the Red Sea Rifting system (Aldamegh et al. 2009, 2010). A small-sized earthquake of Mw 4.0 struck the Arabian Shield on 3rd, November 2017, $24 \mathrm{~km}$ from the eastern coastline of the Red Sea. The earthquake occurred in the Asir terrane, which is one of the intra-oceanic island-arc-terranes and forms the south-western part of the Arabian shield. It comprises north-trending belts of sedimentary and plutonic rocks that have been metamorphosed to varying degrees and fissured by numerous dextral shear zones (Johnson et al. 2001, 2011). Figure 1 shows the regional tectonic boundaries (Johnson et al. 2011), the surface faults, seismic stations and the spatial distribution of epicenters in the epicentral area during the period from 2002 to 2018.

The Arabian Shield (950-550 Ma) was earlier a part of the Neoproterozoic Arabian-Nubian Shield that underwent several phases of amalgamation and postamalgamation tectonic processes which resulted in the formation of several heterogeneous terranes separated by suture zones (Stoeser and Camp 1985; Blasband et al. 2000; Johnson 2003). These terranes include the Midyan, Hijaz, Jeddah and Asir terranes to the west and the Afif, ArRayn, Ad-Dawadimi, and Hail terranes to the east (Hargrove et al. 2006; Bamousa 2103); a simplified geological map is shown in Fig. 2. The Najd Fault System (540-620 Ma) is a complex set of sinistral strike-slip faults and ductile shear zones that formed as a result of a broad zone of NW-SE directed crustal extension that

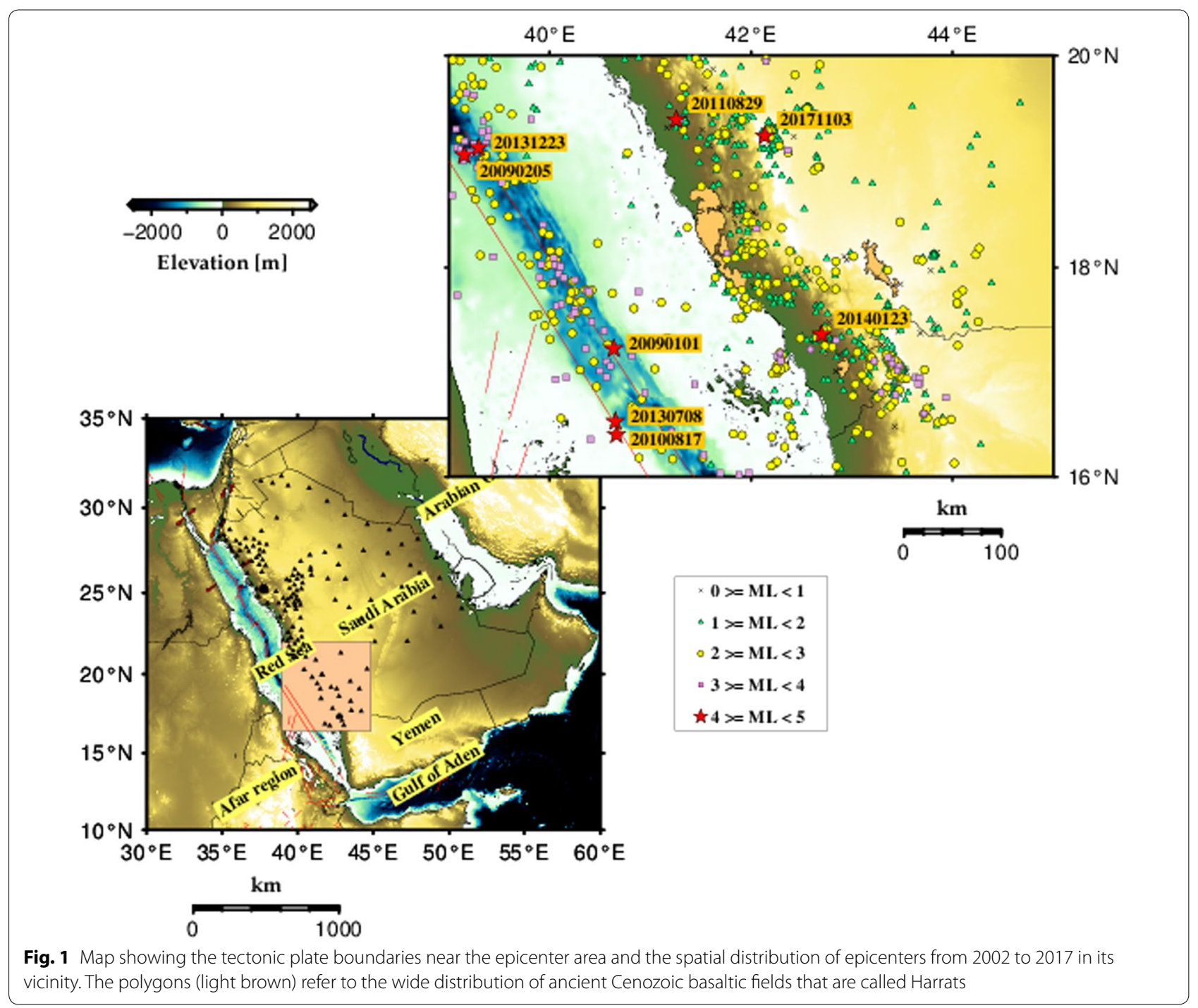




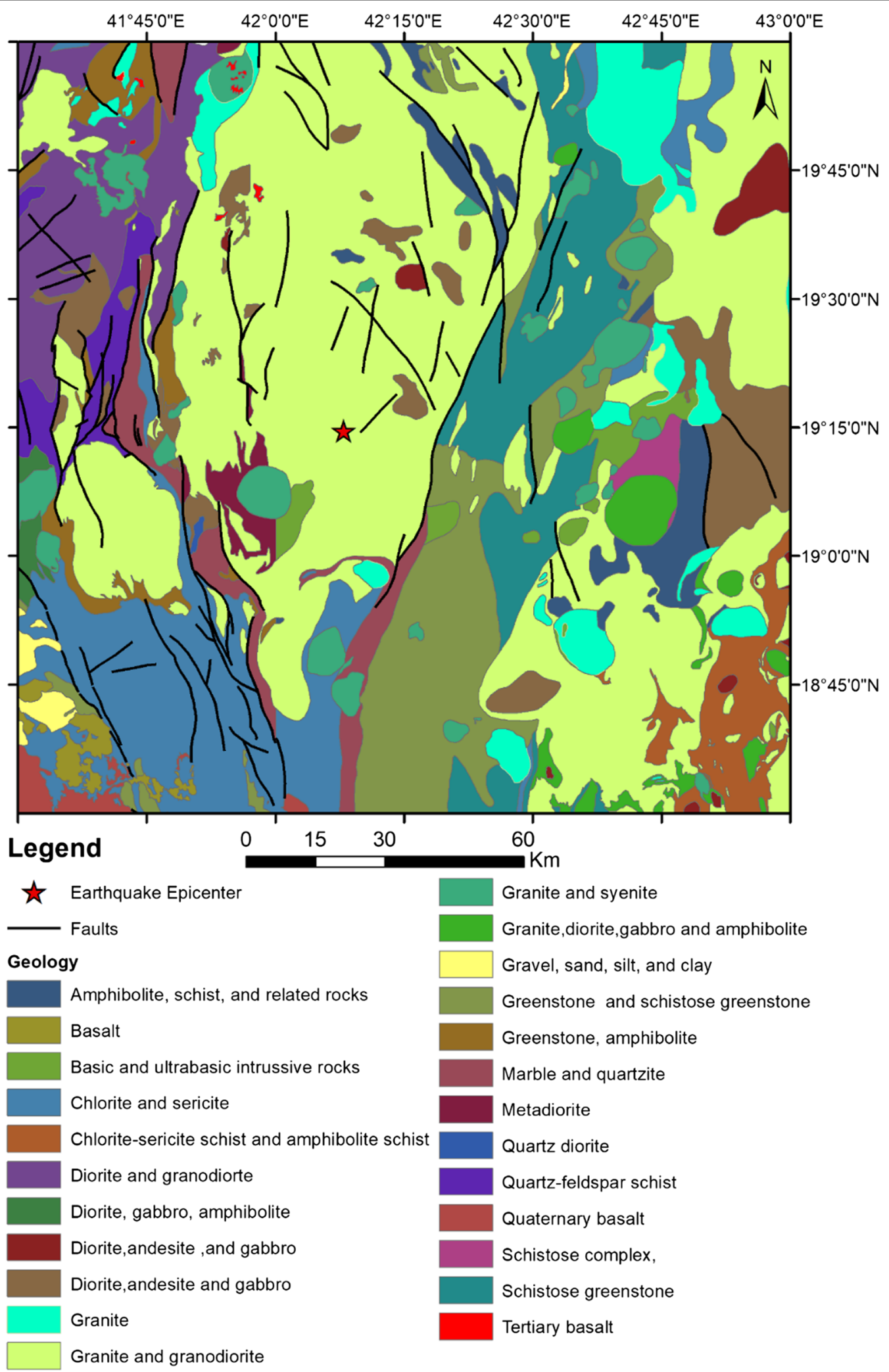

Fig. 2 Geological setting of the study area (modified after Brown and Jackson 1962) 
accompanied juvenile continental crustal formation in the Arabian-Nubian shield (Stern 1985). Finally, the separation of the African and Arabian shields during the Oligocene Epoch initiated due to the extensional stresses associated with an upwelling of active magmas and magmatic intrusions beneath the Arabian Shield. The separation of the African and Arabian shields is manifested in the Arabian Shield by three prominent systems of dextral NE to ENE strike-slip faults, normal NW faults, and sinistral NNW strike-slip faults (Al Ganad et al. 1994; Johnson 1998; Fournier et al. 2007); where seismic activities occur. To the south of the 2017 Namas earthquake, a prominent earthquake occurred in 2014 in the coastal city of Jizan. This earthquake exhibited a focal mechanism solution of dextral strike-slip faulting over the ENE fault trend; implying the rejuvenation of a vertical fault in the Precambrian basement rocks (Abdelfattah et al. 2017).

Since earthquake occurrences are the only direct witness of active deformation, the analysis of recent earthquakes recorded by the Saudi Seismic Network (SSN) provides an impetus toward understanding the presentday stress fields that are responsible for the lithospheric deformation in the Arabian Shield. For this reason, we relocated the hypocenters and we used the moment-tensor inversion and $\mathrm{P}$-wave polarity techniques to retrieve the focal mechanism solutions for the mainshock and aftershocks, which in turn were inverted using the stress tensor inversion. Moreover, the stress drops were calculated using a circular crack model in order to quantify the characteristics of the respective sequence. We determined the focal mechanisms and source parameters for 10 earthquakes with magnitudes ranging from 2.0 to 4.0, revealing dextral strike-slip motion along the NE fault plane and similar source characteristics of shallow plateboundary earthquakes.

\section{Locations and focal mechanism analysis}

The seismic activity in Saudi Arabia is monitored by the broadband seismic network (Fig. 1), which is operated by the Saudi Geological Survey (SGS) (Endo et al. 2007). The stations are equipped with three-component broadband seismometers. The waveforms are digitized by 24 -bit A/D at a sampling rate of 100 samples $\mathrm{s}^{-1}$. The waveforms in the present study were examined to remove the recordings of seismic stations that were characterized by a low signal-to-noise ratio.

\section{Earthquake location}

The hypocenter location was determined using the ELOCATE code (Herrmann and Ammon 2004) and the velocity model of the Arabian Shield (Rodgers et al. 1999). The arrival times of $\mathrm{P}$-wave and S-waves were picked manually from the vertical and horizontal seismograms, respectively. Hypocenters of aftershocks were relocated by the master event method, using the difference of P-wave arrival times between the master and relative events at the nearest stations using the double-difference relocation technique (Waldhauser and Ellsworth 2000). To improve the precision in reading the arrival times, the differential arrival times of P-waves were measured by the cross-correlation technique in the time domain. The waveform similarity for pairs of earthquakes was investigated in the time domain. The waveform crosscorrelations were applied for $\mathrm{P}$ - and $\mathrm{S}$-waves separately using the vertical component for the $\mathrm{P}$-wave and the $\mathrm{N}-\mathrm{S}$ component for the $\mathrm{S}$ wave. A time window of $1 \mathrm{~s}$ that started $0.1 \mathrm{~s}$ before the $\mathrm{P}$ and $\mathrm{S}$ arrivals, separately, was filtered using a 4th order Butterworth band-pass filter for frequencies between 1 and $4 \mathrm{~Hz}$. The Hanning window was applied to trap off the trace ends. The cubicspline interpolation technique (Hokstad et al. 1998) was used in order to increase the accuracy of the one-sample interval of the differential times that were used to relocate the relative events. The differential times measured with correlation coefficients greater than 0.7 , suggests similar waveforms were used to obtain the precise relative locations. The average root-mean-square (RMS) that measured the time difference between the observed and calculated travel times were found to be of $0.05 \pm 0.02 \mathrm{~s}$. The uncertainty in the epicenter and focal depth is $1.2 \pm 0.1 \mathrm{~km}$ and $1.7 \pm 0.1 \mathrm{~km}$, respectively. Figure 3 shows the spatial distribution of relocated epicenters and hypocenters with respect to the latitudes and longitudes, and the seismic stations used in relocations. The hypocenter relocations and their uncertainties for the mainshock and its aftershocks are listed in Table 1.

\section{Determination of focal mechanisms}

Based on the assumption of the point-source model, the regional moment-tensor inversion technique of Ichinose et al. (2003) was applied to retrieve the source mechanism, focal depth and origin time of the mainshock that occurred on the 3rd of November 2017. The technique avoids the potential trade-offs between the origin time and the focal depth by using a grid-search method over a range of focal depths and origin times. The optimum solution is inferred from the variance reduction function between the observed and synthetic seismograms. The inversion was carried out using the complete seismograms of seven seismic stations that showed appropriate signal-to-noise ratios and good azimuthal coverage around the epicenter. The instrumental effect was removed from the waveform to obtain the actual ground velocity. Subsequently, the waveform was filtered by the band-pass filter in the frequency ranges 


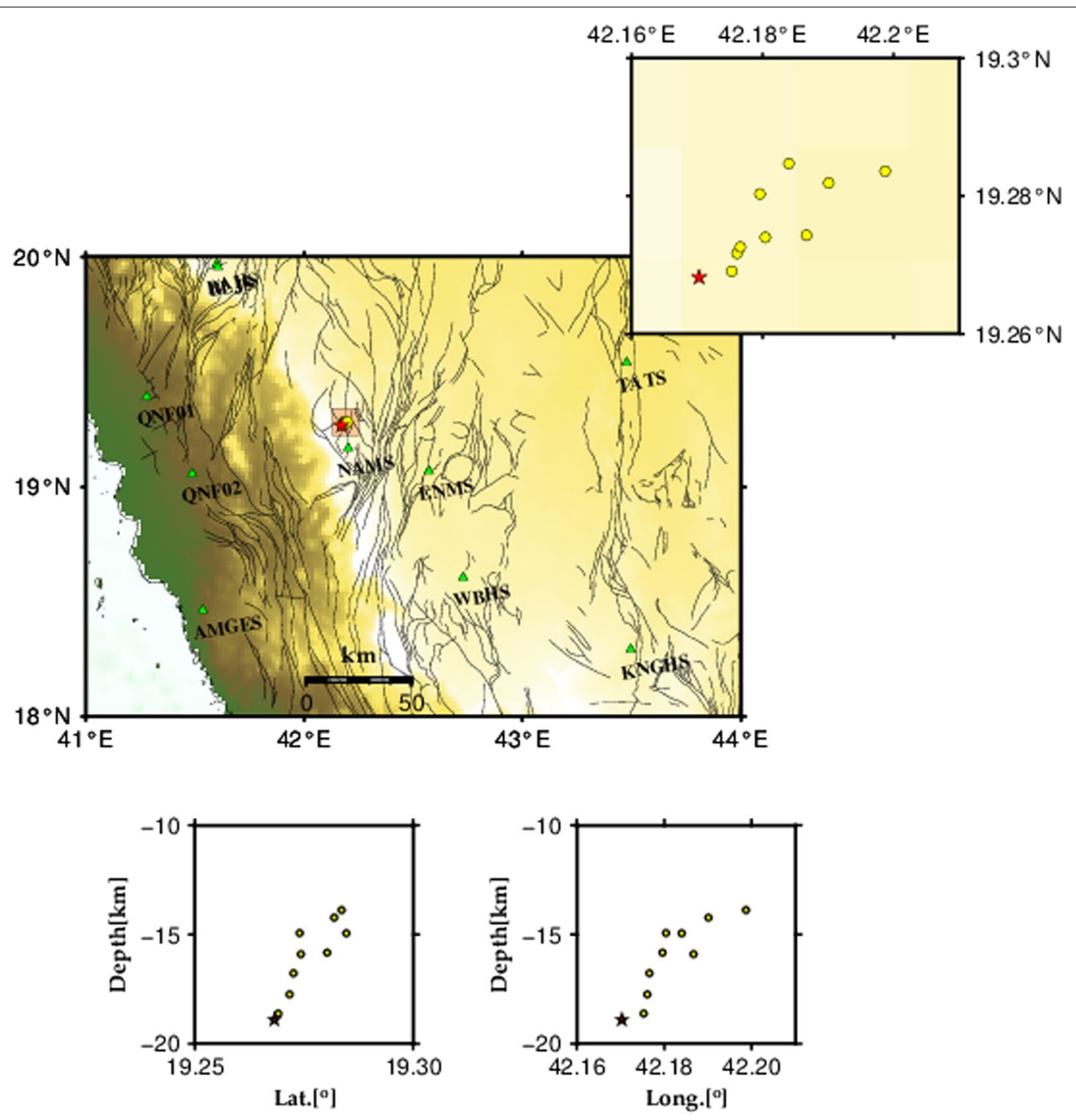

Fig. 3 The upper panel shows the spatial distribution of epicenters of events of moment magnitude ranging from 2.0 to 4.0. The red star refers to the mainshock and the yellow circles correspond to the largest aftershocks. Green triangles show the nearest seismic stations that recorded the events. The map shows also the surface faults represented by thin solid lines as taken from SGS. The upper right panel shows a zoom of epicentral area and the epicenter distributions. The lower panels show the vertical distribution of hypocenters along both latitude and longitude

from 0.01 to $0.1 \mathrm{~Hz}$ to satisfy the assumption of a pointsource model that is valid for the waveforms of much larger wavelengths than the source dimension. The two horizontal components were rotated to obtain radial and transversal seismograms. A suite of Green's functions was computed along the source-to-receiver paths, shown in Fig. 4, and over a range of focal depths using a generic velocity model that is adequate to model long-period seismograms. The Green's functions were estimated using the fast reflectivity and $\mathrm{f}-\mathrm{k}$ summation computer code of Zeng and Anderson (1995). To avoid the potential trade-offs between the origin time and the focal depth, we searched for the optimum solution over a range of focal depths and origin time shifts, throughout the maximization of the variance reduction function. The empirical relation of Mancilla (2001) was used to calculate the quality factors for $\mathrm{P}$-wave $\left(Q_{\mathrm{P}}=9 / 4 Q_{\mathrm{S}}\right)$ and $\mathrm{S}$-wave $\left(Q_{S}=V_{S} / 10\right)$. To resolve the focal depth and origin times, a series of moment-tensor inversions were performed for different focal depths and origin times. The Green's function was computed using two alternative velocity models of Rodgers et al. (1999) and Tang et al. (2016) for a series of focal depths ranging from 2 to $40 \mathrm{~km}$ with $2 \mathrm{~km}$ intervals and for origin times within the range from $-3 \mathrm{~s}$ to $+3 \mathrm{~s}$, shifted with a sampling rate of $1 \mathrm{~s}$ relative to 01:06:52.0 UTC. Figure 5 shows the variance reductions 


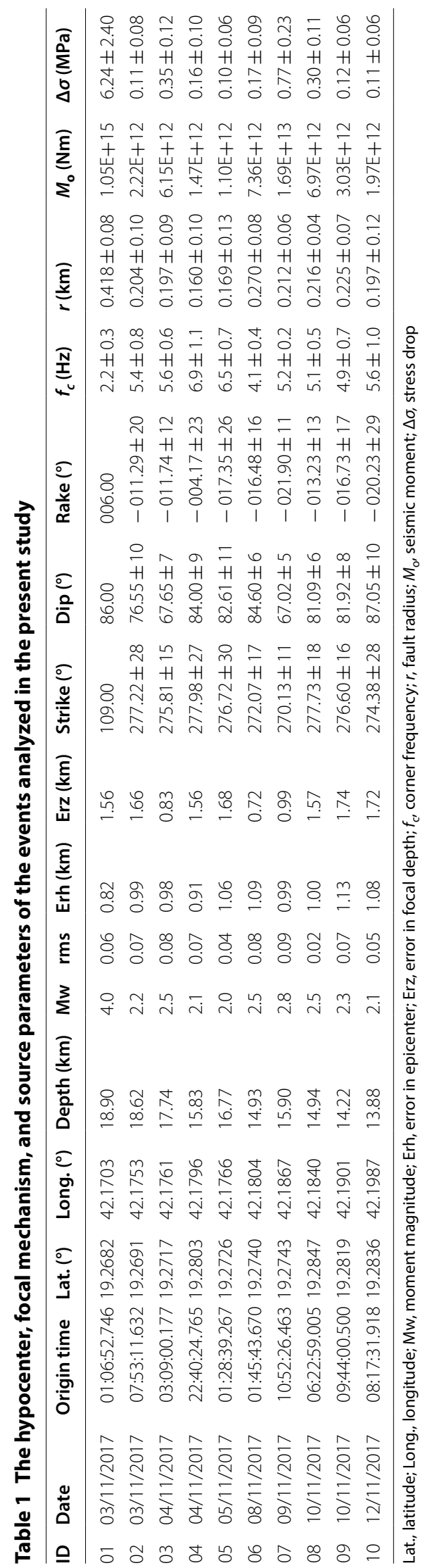



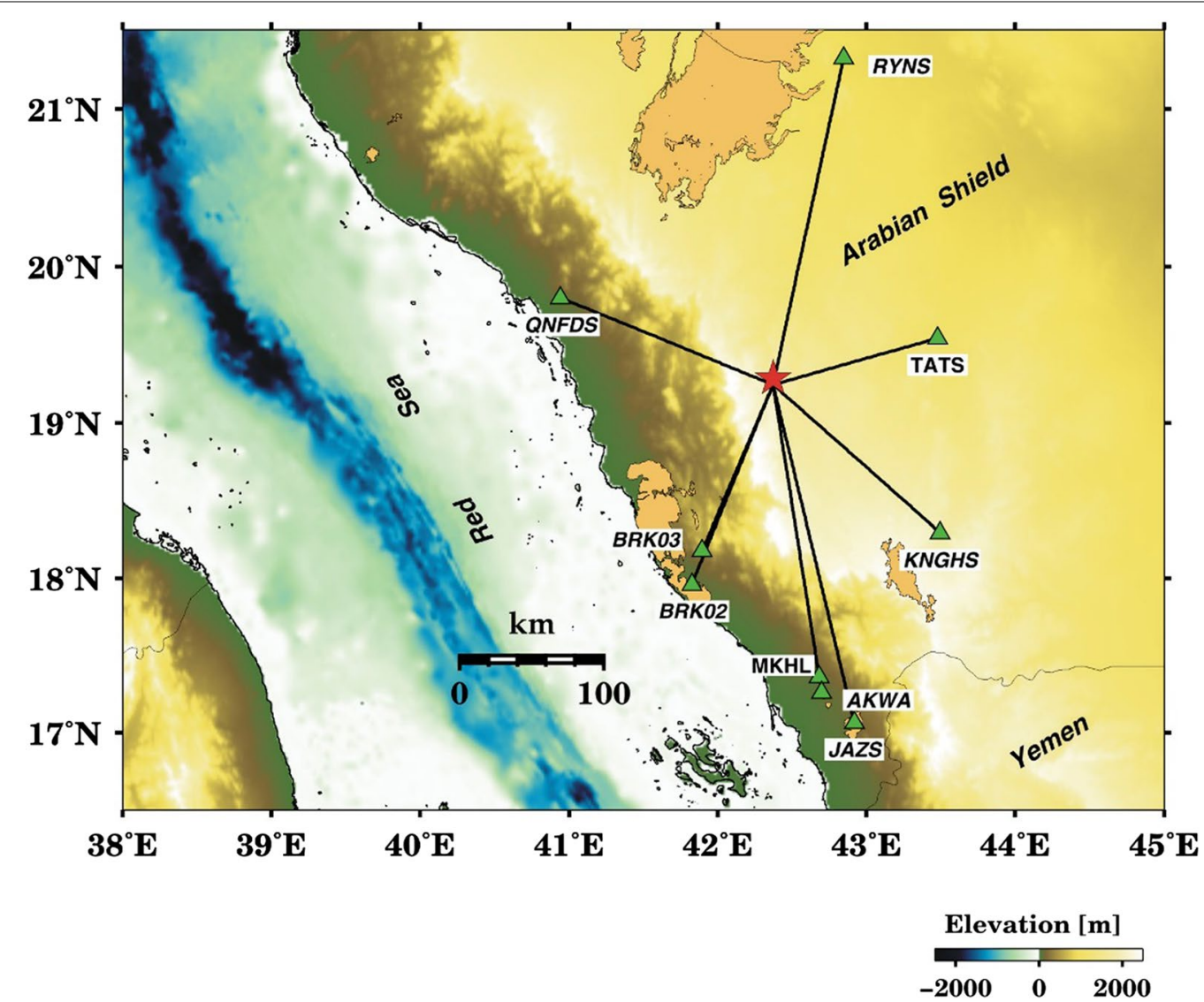

Fig. 4 Map shows the location of the mainshock and the spatial distribution of seismic stations (green triangles) used to retrieve the space parameters of the mainshock (focal mechanism, origin time, and focal depth) from the regional waveform inversion

that quantify the fitness error between the observed and synthetic seismograms. The solution, corresponding to the origin time of 01:06:53.0 UTC and focal depth of $18 \mathrm{~km}$, indicates the best-fit solution. Further, the solution shows a seismic moment of $1.14 \mathrm{E}+15 \mathrm{Nm}$ and a corresponding moment magnitude of 4.0 that was calculated using the relation of Hanks and Kanamori (1979). Figure $6 \mathrm{a}, \mathrm{b}$ shows the comparison between the observed and synthetic seismograms computed for the optimum solutions of deviatoric and full moment-tensor solutions derived from the regional waveform inversion using the velocity models of Rodgers et al. (1999) and Tang et al. (2016). The moment-tensor solution revealed 9.5\%, $11.3 \%$, and $79.2 \%$ for ISO, CLVD, and DC components, respectively. The preferred moment-tensor solution is consistent with the P-wave polarities identified at the analyzed seismic stations.

Based on the assumption of a double-couple source model, focal mechanisms of nine aftershocks were retrieved using the inversion from polarities of P-waves using the program Pman (Suetsugu 1998) that was developed to run under the Linux operating system taking into calculations the take-off angles computed using the code ANGGRA (Jansky 2001). The lower hemisphere projection was used for plotting the P-wave polarities that were picked manually at the available stations. The two nodal planes were identified using the program Pman (Suetsugu 1998) that runs using the Linux operating system.

The focal mechanism solutions show strike-slip faulting with two nodal planes trending ENE and NNE (Fig. 7a). From the tectonic point of view, the two nodal planes can be plausible in the Arabian Shield (Abdelfattah et al. 2017). The fault parameters that were retrieved from the double-couple focal mechanism solution are listed in Table 1. The fault-plane solutions using polarities always show uncertainties depending on the size of gaps in the station distribution around the epicenter. The fault-plane solution uncertainties were performed by taking into consideration all possible solutions matching the polarities and then the standard deviation was estimated for strike, dip and rake. 


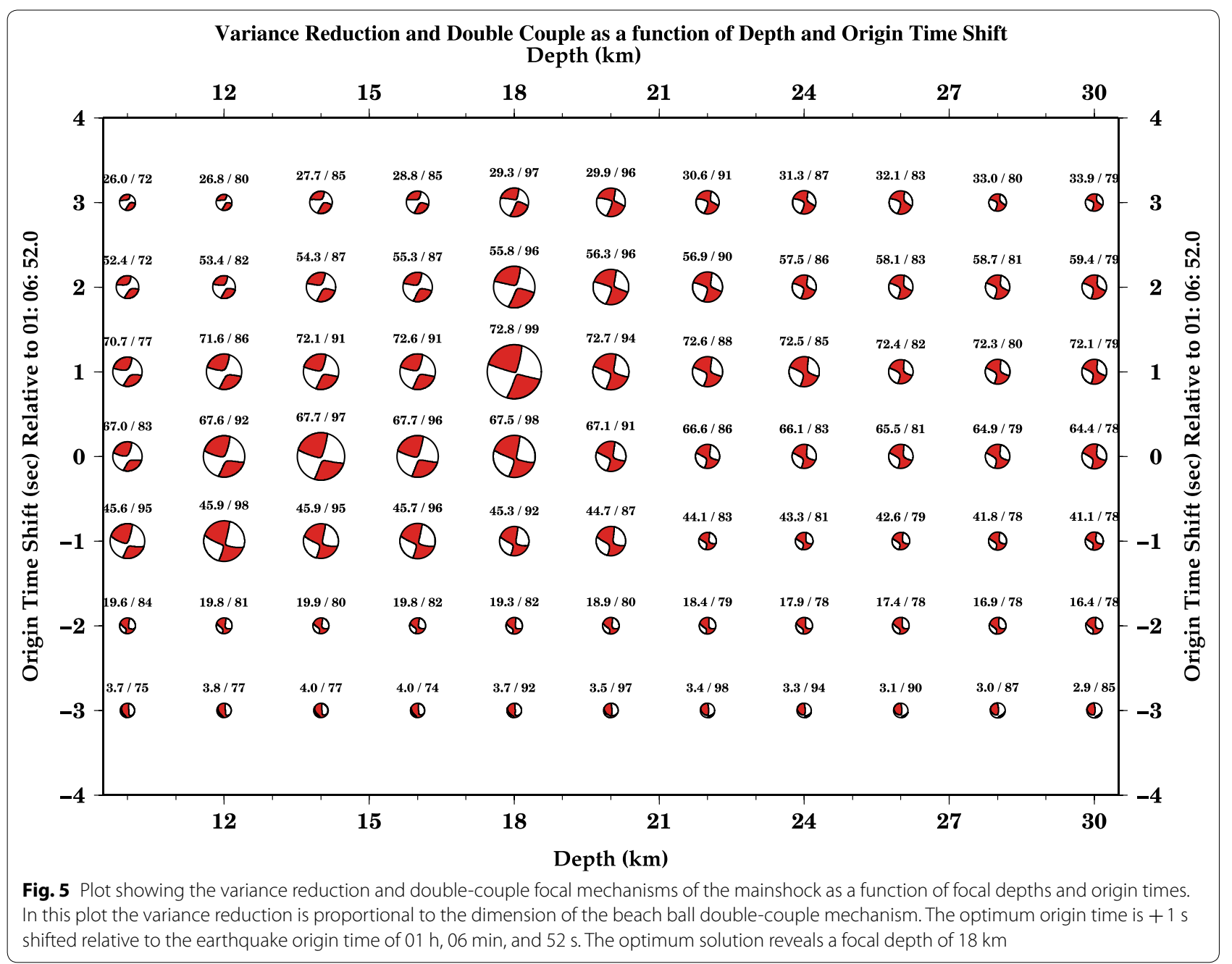

\section{Stress tensor inversion}

The fracture process on the fault zone is controlled by many factors such as the shear stress, pore-fluid pressure, fault friction and weakness of the focal zone. Based on the focal mechanism solutions obtained from the previous step, the recent stress tensor inversion technique developed by Vavryćuk $(2011,2014)$ was applied to determine the orientation of local stress axes and activated faults and the stress ratio in the dislocation zone. The variation in focal mechanism solutions may bias stress ratio and the selection of the activated fault plane from two nodal planes. This can be resolved by incorporating an algorithm to identify the fault plane based on evaluating the fault instability $(I)$ as introduced by Vavryćuk (2011, 2014):

$$
I=\frac{\tau+\mu(\sigma+1)}{\mu+\sqrt{1+\mu^{2}}},
$$

where $\mu$ is the friction coefficient, and $\tau$ and $\sigma$ are the normalized shear normal tractions on a fault. The method consists of maximizing the so-called slip shear stress component using an iterative algorithm based on robust grid-search inversion over the friction coefficients ranging between 0.2 and 1.0. This avoids the necessity to identify the fault plane among the different nodal planes. The stress and fault orientations determined based on the fault instability concept is run in several iterations. In the first iteration, the stress is obtained by random perturbation of the focal mechanism dataset. The obtained stress provides the identification of the activated fault planes based on the fault instability and the stress inversion is turned on again. This process is repeated for 5 to 10 iterations to obtain the final stress. For this purpose, the open-access STRESSINVERSE code written in MATLAB (Vavryćuk 2014) was used. Four parameters of the stress tensor are recovered; the orientation of the principal stress axes; $\sigma_{1}, \sigma_{2}$, and $\sigma_{3}$ and the shape ratio $R$. The uncertainties were assessed by random perturbation of 


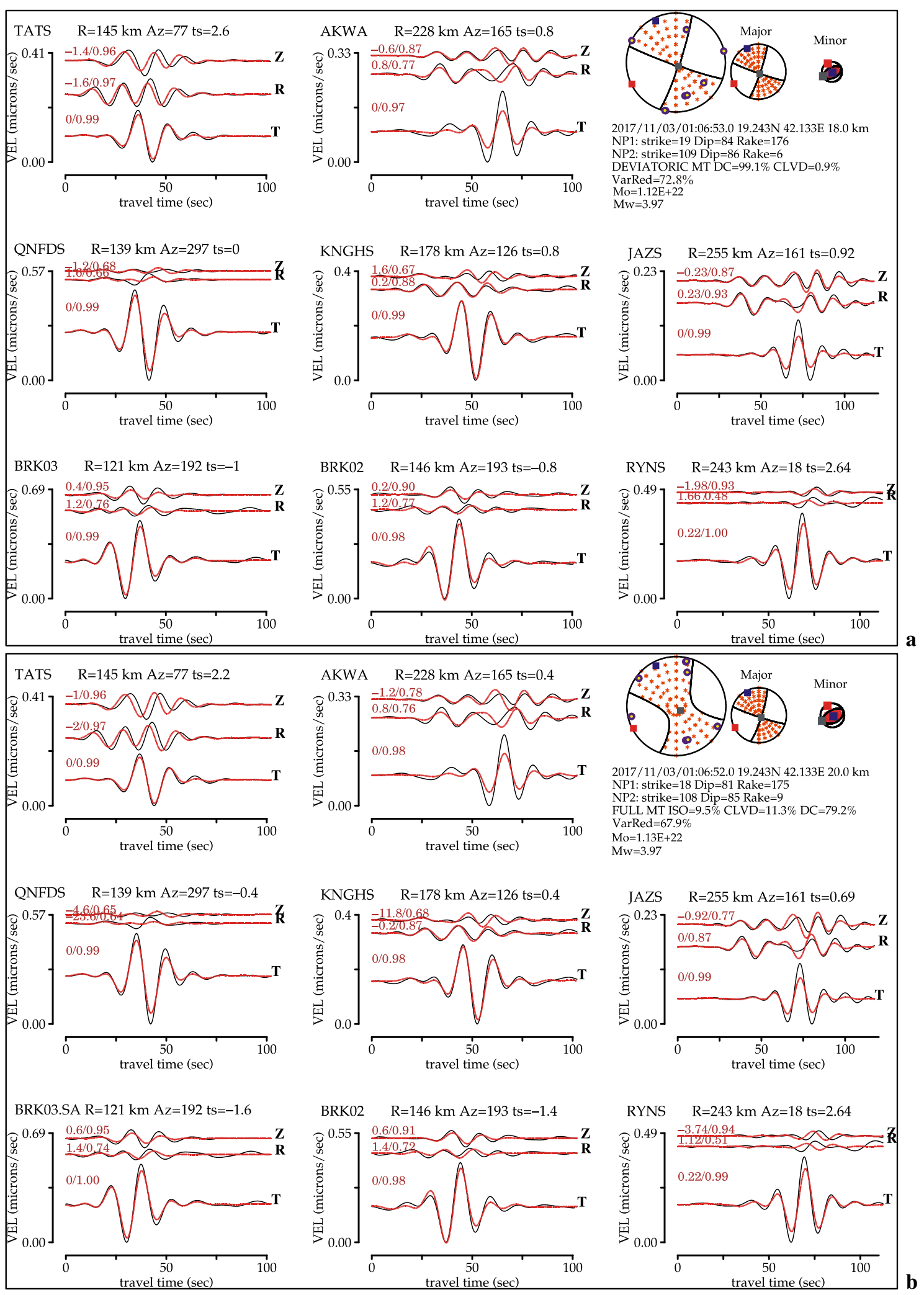

Fig. 6 Comparison between the observed (black lines) and the synthetic velocity waveforms for the optimum solutions obtained from the regional waveform inversion a the deviatoric moment-tensor solution using the velocity model of Rodgers et al. (1999) and $\mathbf{b}$ the full moment-tensor solution using the velocity model of Rodgers et al. (1999) 


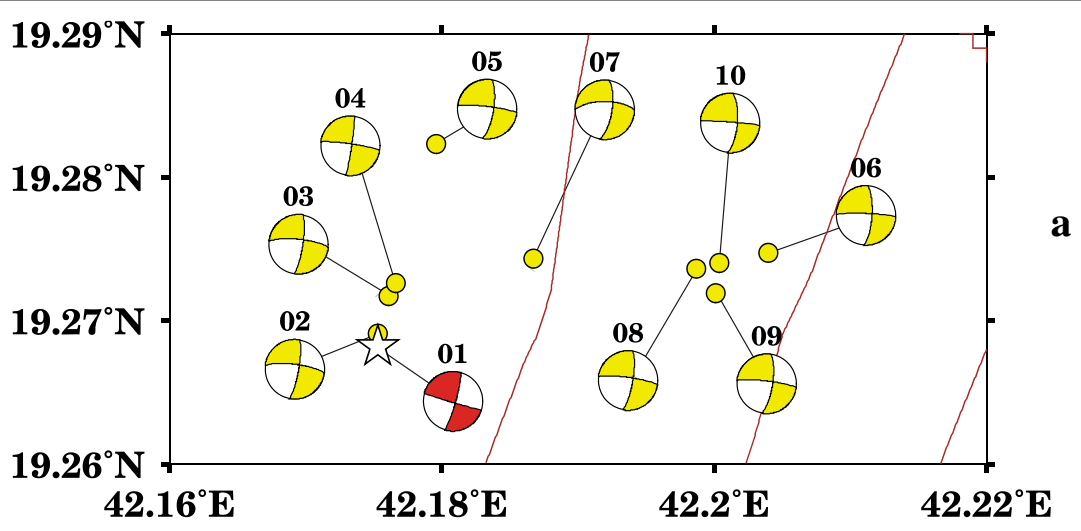

Principal stress and P/T axes

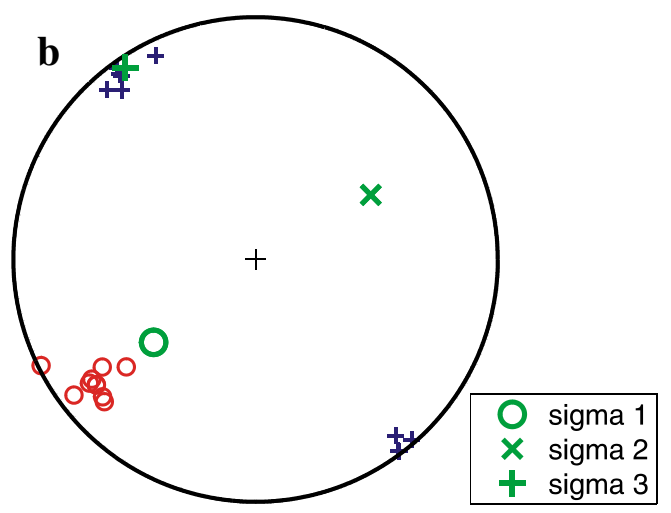

Confidence of principal stress axes

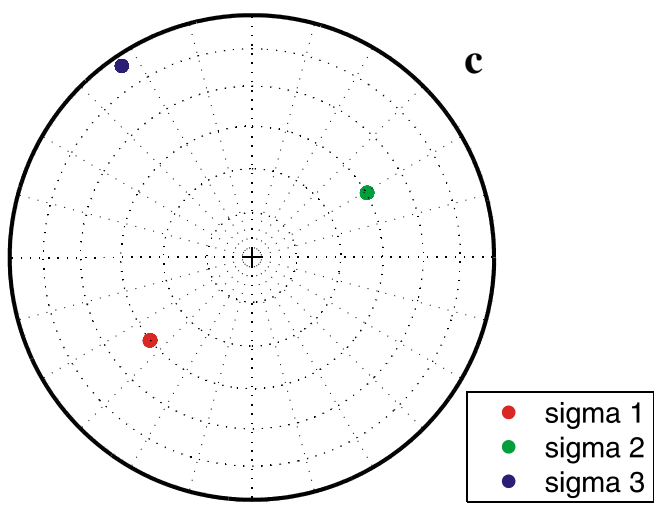

Mohr circle diagram
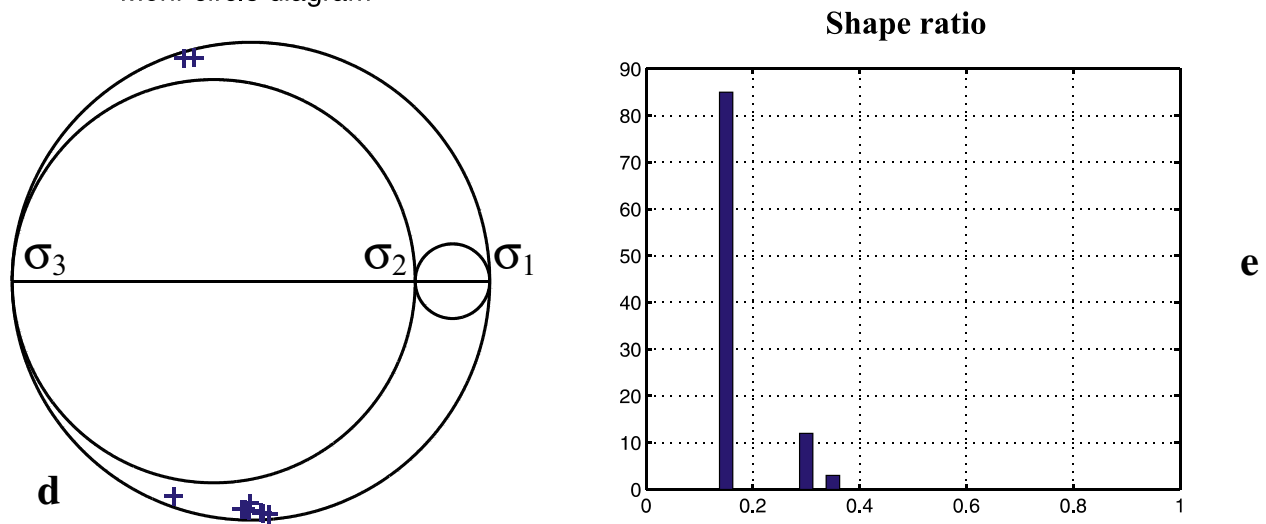

Fig. 7 Iterative inversion of stress and fault orientations. The plot shows: a the distribution of focal mechanisms of the mainshock (red beach ball) and aftershocks (yellow beach ball) of the fault parameters listed in Table 1, b P-axes (red circles) and T-axes (blue plus signs) and the corresponding principal stress directions $\left(\sigma_{1}, \sigma_{2}\right.$, and $\left.\sigma_{3}\right)$, c confidence of principal stress axes retrieved from random perturbation of the focal mechanism dataset. d Mohr's circle diagram with the positions of fault planes, and $\mathbf{e}$ the stress ratio histogram for the 2017 earthquake sequence

the focal mechanism dataset contaminated with artificial noise. A random noise of 100 realizations was used in the inversion with a level of noise of $10^{\circ}$ to the estimated accuracy of input focal mechanisms. After a total number of 6 iterations, the inversion process is terminated.
The focal mechanism solutions of a total number of 10 events were inverted to recover the tectonic stress regime in the seismogenic zone. Figure $7 \mathrm{~b}-\mathrm{e}$ shows the results of the stress inversion with a stress ratio of 0.16 . The faultplane solutions display a cluster distribution of $\mathrm{P}$ and 
$\mathrm{T}$ axes indicating that the axes $\sigma_{1}$ and $\sigma_{3}$ are well constrained. The optimum solution reflects a contemporary shear stress regime characterized by major compressive stress $\left(\sigma_{1}\right)$ of $44.9^{\circ}$ plunge and $230.9^{\circ} \mathrm{SW}$ trend, the intermediate compressive stress $\left(\sigma_{2}\right)$ of $44.7^{\circ}$ plunge and $60.7^{\circ}$ $\mathrm{NE}$ trend, and the minor compressive stress $\left(\sigma_{3}\right)$ with $4.9^{\circ}$ shallow plunge and $325.8^{\circ} \mathrm{NW}$ trend; corresponding to the dominant strike-slip stress regime as illustrated in Fig. 7b. The value of the stress ratio is low at $0.15 \pm 0.09$. The confidence level is shown in Fig. 7c, reflecting the accuracy of inverted focal mechanisms considering the assumption of the inversion affects the shape ratio value as shown in Fig. 7e. The instability of the fault plane was measurable from the projections of fault planes on Mohr's circle diagram. The distributions of fault planes in Mohr's circle diagram imply high shear stress (Fig. 7d). The parameters of principal focal mechanisms are listed in Table 2. The inversion shows that $80 \%$ of fault-plane solutions are located in the lower Mohr's semi-circle; indicating a fault oriented to the NE with a stress ratio of $0.15 \pm 0.09$ and a low friction coefficient of 0.3 . The fault planes are highly stable and have orientations with a strike of $26.9^{\circ}$, a dip of $60.6^{\circ}$, and a rake of $-143.8^{\circ}$. On the other hand, the conjugate fault is oriented to a strike of $262.5^{\circ}$, a dip of $69.4^{\circ}$, and a rake of $-41.3^{\circ}$. However, the number of events is not sufficient for accurate inversion to provide the most likely orientations of faults for the computed stress regime. Therefore, they should not be directly interpreted as supporting evidence for conjugate faulting.

\section{Stress drop}

In general, earthquakes occur on pre-existing active faults due to the regional stress regime, and therefore similar focal mechanisms are observable. Some recent studies (Skoumal et al. 2015; Schultz et al. 2015) show that the focal mechanism solutions of induced events imply a rejuvenation of pre-existing faults which are consistent with the regional stress regime. The so-called stress drop, that measures the difference between the stress before and after the occurrence of an earthquake, may potentially be used to distinguish between the earthquakes originating from different geodynamic processes.

In this analysis, we estimate the amplitude spectrum for $\mathrm{P}$ - and $\mathrm{S}$-waves. The signal-to-noise ratio (SNR) is

Table 2 Principal fault-plane solutions of the 2017 earthquake sequence

\begin{tabular}{lccc}
\hline Optimum fault trends & Strike $\left(^{\circ}\right)$ & Dip $\left({ }^{\circ}\right)$ & Rake $\left({ }^{\circ}\right)$ \\
\hline Upper Mohr's semi-circle & 262.5 & 69.4 & -41.3 \\
Lower Mohr's semi-circle & 26.9 & 60.6 & -143.8 \\
\hline
\end{tabular}

evaluated to satisfy a minimum average value of 3 for frequencies over a minimum of $20 \mathrm{~Hz}$ bandwidth. A time window of 1-2 s, that was selected based on the hypocentral distance, was used to compute the amplitude spectrum for pre-event noise and seismic signal. Data from only those intervals with a SNR $\geq 3$ are used and the amplitude spectrum was calculated using the fast-Fourier transform. The evaluation of stress drop requires constraints on the influence of propagation path and site effects on seismograms to isolate the source term. We use a spectral ratio based on empirical Green's function (EGF) method which assumes that two collocated earthquakes share the same propagation path and site effects (Huang et al. 2016). An example of processing is shown in Fig. 8. The spectral ratio approach allows us to remove the source-to-receiver path and site effects to constrain the source effect, provided the lower and higher corner frequencies can be precisely determined for kernel and master events. For this purpose, we selected the events that showed a minimum magnitude difference of 1.0 and the crosscorrelation coefficient greater than 0.7. The EGF events are listed in Table 1. Once the higher frequency plateau of small events is observable, the corner frequencies of the master and kernel events are estimated by fitting the spectral ratios using the following model (Brune 1970):

$$
\frac{U_{m}}{U_{g}}=\frac{M_{m}}{M_{g}} \sqrt{\frac{1+\left(\frac{f}{f_{\mathrm{cg}}}\right)^{4}}{1+\left(\frac{f}{f_{\mathrm{cm}}}\right)^{4}}}
$$

where $\left(M_{m} / M_{g}\right)$ is the seismic moment ratio between the master event seismic moment $\left(M_{m}\right)$ and the kernel event seismic moment $\left(M_{g}\right)$. The quantities $f_{\mathrm{cm}}$ and $f_{\mathrm{cg}}$ are the corner frequencies for the master and the kernel events, respectively. We applied the grid-search method of de Lorenzo et al. (2010) to fit the spectral ratios, using Eq. 2, and then determined the seismic moment ratio and the corner frequencies.

The seismic moment for EGF events was calculated using the seismic moment for the mainshock that was obtained from the moment-tensor solution and the seismic moment ratio $\left(M_{01} / M_{02}\right)$. The source radius was estimated using the mean corner frequency and the following relation (Madariaga 1976);

$$
r=\frac{k v}{f_{c}}
$$

where $\mathrm{r}$ is the fault radius, $\mathrm{v}$ is the wave velocity, $k$ is a constant equal to $C / 2 \pi$ ( 0.32 for $\mathrm{P}$-waves and 0.21 for $\mathrm{S}$-waves), assuming the rupture velocity is $90 \%$ of the 


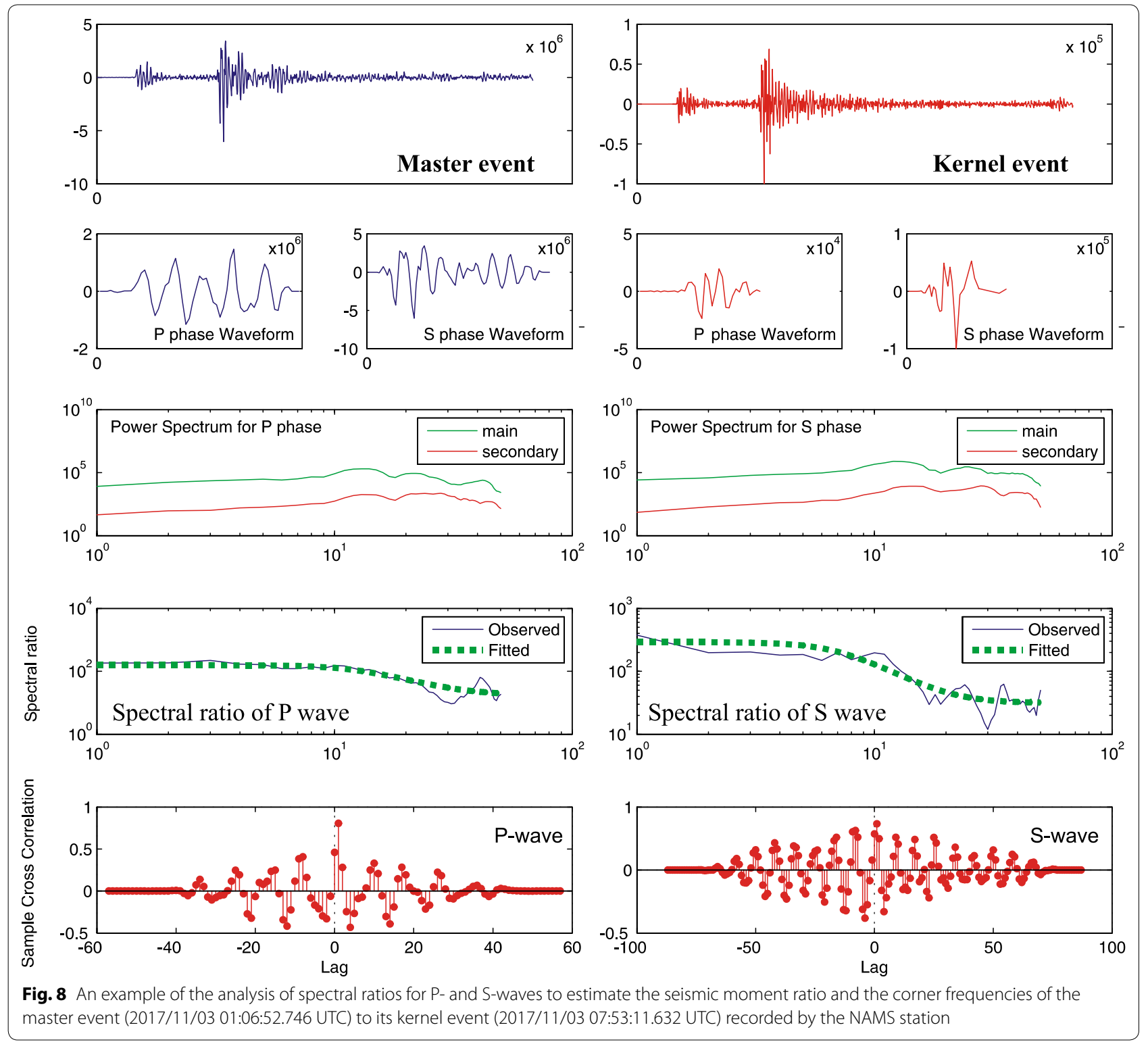

shear wave velocity that is equivalent to $3.93 \mathrm{~km} / \mathrm{s}$ in the source region (Rodgers et al. 1999). Once the seismic moment $M_{0}$ and the radius $\mathrm{r}$ of the circular crack are known, the stress drop is calculated using the following equation (Keilis-Borok 1959):

$$
\Delta \sigma=\frac{7}{16} \frac{M_{o}}{r^{3}},
$$

where $M_{o}$ is the seismic moment. The estimated source parameters, seismic moments, fault radius, and stress drops, are listed in Table 1. The seismic moments and corner frequencies, listed in Table 1 , are the average value estimated using a number of EGF events. Figure 9a shows the relationship between the source radius and seismic moment among three lines representing the constant stress drop scale at $0.1,1$, and $10 \mathrm{MPa}$. Estimates of source parameters revealed that seismic moments are observed within the range from $1.1 \mathrm{E}+12 \mathrm{Nm}$ to $1.1 \mathrm{E}+15 \mathrm{Nm}$. The circular crack model estimates the source radius of $0.16-0.50 \mathrm{~km}$. Estimates of stress drops range from 0.1 to $6.2 \mathrm{MPa}$ with a median of $0.16 \mathrm{MPa}$. $90 \%$ of the dataset, representing 9 events, showed a dependence of stress drop on the moment. The mainshock stress drop has a typical value similar to that reported for shallow intraplate earthquakes (Ruff 2002). Figure $9 \mathrm{~b}$ shows the distribution of stress drop values and moment magnitude with a mean of $0.16 \mathrm{MPa}$. The source 

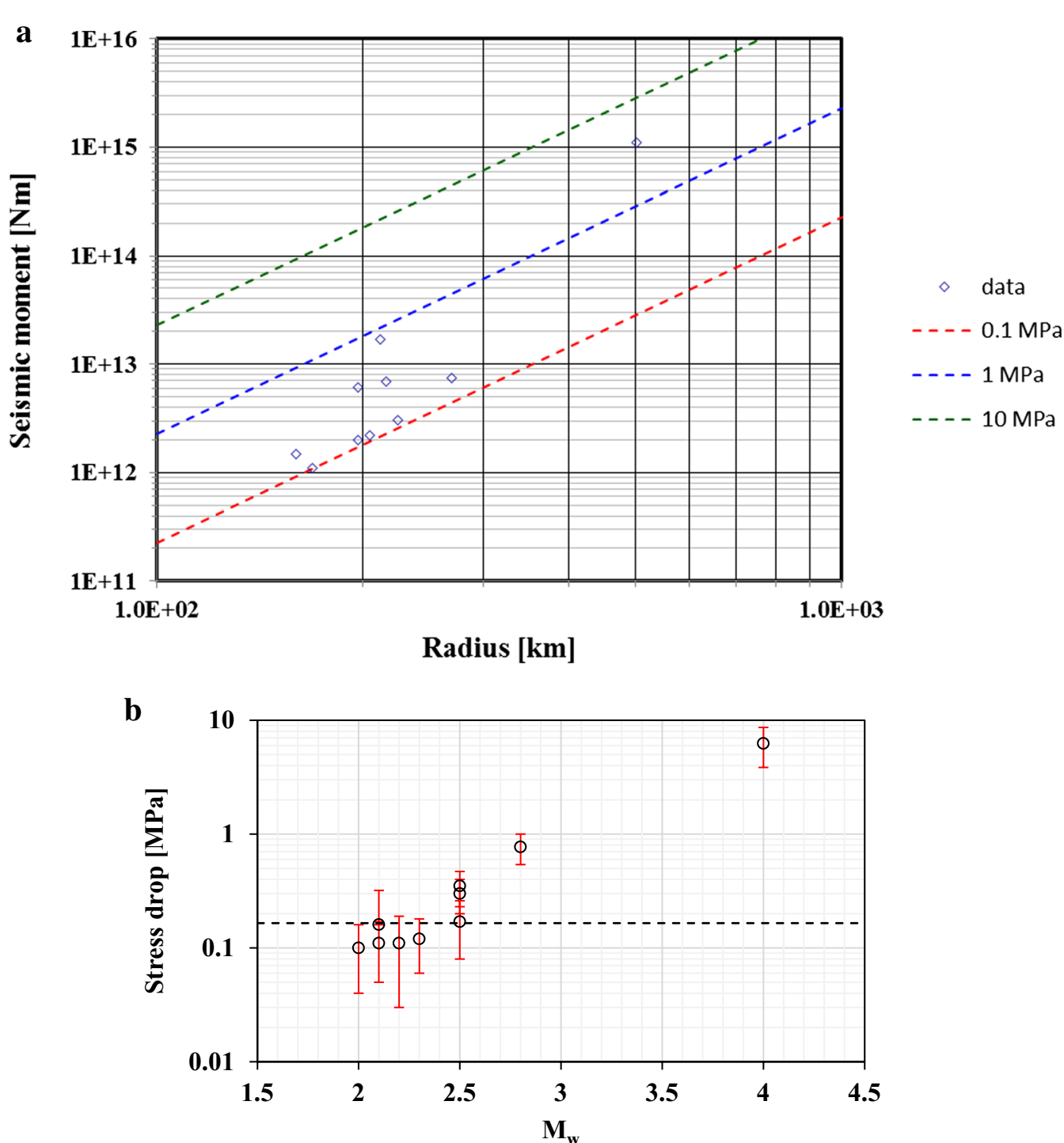

Fig. 9 Plot showing a the distribution of the seismic moments versus the fault radii with constant stress drops representing by solid lines for 0.1 , 1.0 , and $10 \mathrm{MPa}$, and $\mathbf{b}$ the distribution of stress drops as a function of moment magnitude (Mw). The dashed line represents the median of stress drop estimates

parameter uncertainties were calculated using the algorithm proposed by Archulleta et al. (1982).

\section{Discussion}

Improved knowledge is an essential key to understand the geodynamic processes that generate the lithospheric deformation, stress and strain localization, and stress release resulting in earthquakes. The geodetic measurements indicated that the southern part of the Red Sea region accommodates by an extensional deformation ranging from $7.1 \pm 0.1$ to $15.4 \pm 0.1 \mathrm{~mm} /$ year in the $\mathrm{N} 20^{\circ}$ E direction between latitudes $15^{\circ} \mathrm{N}$ and $20^{\circ} \mathrm{N}$ as reported by ArRajehi et al. (2010). The study of source characteristics of seismic dislocation zones, which are widely distributed in the vicinity of the complex geodynamic setting associated with the large-scale regional tectonics of the Red Sea opening, can lead to a new understanding of peculiar seismicity in the Arabian Shield.

In this study, we present the results from the waveform analysis of the 2017 earthquake sequence that occurred in the eastern flank of the Red Sea, Saudi Arabia. The focal depth of the mainshock (18-20 $\pm 2 \mathrm{~km})$, as retrieved from the waveform inversion using two velocity models (Rodgers et al. 1999; Tang et al. 2016), is consistent 
with the focal depths determined by the absolute location. The Moho discontinuity beneath the epicentral area demarcates the upper crust $(0-15 \mathrm{~km})$ and lower crust (12.5-30.0 km), as deduced by Tang et al. (2016) using the $H-\kappa$ stacking analyses and joint inversion technique of P-receiver functions and Rayleigh waves dispersion curves. An average crustal thickness of $41.6 \mathrm{~km}$ is reported in the area (Aldamegh et al. 2005; Tkalčić et al. 2006). Although this seismic sequence is characterized by a relatively low magnitude, it has some potential to reveal the present-day tectonic stress field in the intra-continental setting. The results obtained from hypocentral relocations, focal mechanism solutions, and stress tensor inversion reveal a dextral strike-slip movement along the NE fault plane. The corresponding focal mechanism solutions showed two distinct nodal planes oriented in the NE-SW and NW-SE directions. The hypocentral distributions of the largest aftershocks $(\mathrm{Mw} \geq 2.0)$ aligned to the NE direction, reflects a unilateral rupture propagation to the updip direction from the mainshock hypocenter. The Mohr's circle diagram, with respect to the positions of fault planes, reveals a dextral strike-slip movement over the NE fault plane that is emphasized by the alignment of the aftershock distributions. It is noteworthy that the present results are inconsistent with large-scale regional tectonics of the Red Sea opening.

The Asir terrane, where the epicentral area is located, is represented by two generations of arc magmatism. The older arc assemblage consists mainly of dioritic to tonalitic plutonic rocks, which were formed between 950 to $800 \mathrm{Ma}$ and included the Namas, Bidaj, and Jiddah terrane (Bokhari and Kramers 1981). The younger arc magmatism comprising the Al-Qarah terrane developed around $740 \mathrm{Ma}$ (Stoeser and Frost 2006). Geological mapping shows that the Asir terrane consists of northtrending litho-structural features (Nehlig et al. 2002). The 680-640 Ma Nabitah suture zone (Schmidt et al. 1979) is a North-South trending major fault zone (Stoeser and Camp 1985). It defines a 100 - to $200-\mathrm{km}$-wide zone of crustal deformation, extending for more than $1000 \mathrm{~km}$ that has been regarded as the site of a collision between the Asir and Hijaz terrane in the west and the Afif terrane in the East. The zone contains abundant serpentinite bodies (Pallister et al. 1987) and has been affected by dextral shearing throughout its ductile and later on brittle history (Johnson and Kattan 2001; Johnson and Woldehaimanot 2003). The 620-540 Ma Ad Damm Shear Zone (Johnson et al. 2001, 2011) is a NE to NNE trending fault zone which separates the Asir terrane from the Jiddah terrane and is characterized by dextral shearing with moderate-to-steep NW plunging stretching lineations (Hamimi et al. 2014). The Asir terrane is affected by dextral shearing in its eastern part and sinistral shearing in its western part and is characterized by old as well as relatively young shearing events. In the epicentral area, the main intra-terrane deformation zone is the Umm Fawal structure that is characterized by dextral strike-slip deformation over the $\mathrm{N}$ to NE fault orientations (Stoeser and Stacey 1988; Stern and Johnson 2010). All the shear zones follow the $\mathrm{N}$ to NE trends. Evidence of ductile followed by brittle deformation shows that the shear zones in the terrane experienced progressive deformation and reactivation (Johnson et al. 2001, 2011). The NE-striking subsurface faults were inferred from the gravity and magnetic data (Gettings 1983). It is noteworthy that the axial rift west to the epicentral area is dissected by a number of well-defined transverse faults (Bosworth 2015). Moreover, the epicentral distributions in Fig. 1 demarcated some of the NE to ENE fault trends at the eastern shores of the Red Sea. Similar enigmatic phenomenon of peculiar seismicity is observed along the western coast of the Red Sea in Egypt (Abdel-Fatth et al. 2008). These observations may rise to suggest a transfer of stress accumulations from large-scale regional tectonics of the Red Sea opening into the eastern flank of the Red Sea across transverse faults. Considering the nearby fault trends, two fault systems are well distinguished in the Arabian Shield; the first system characterized by an extensional field similar to that is responsible for the Red Sea rifting system and the second one represents the NE fault trends of dextral strike-slip mechanisms formed by the Pan-African orogeny. It is worth stressing that the 2014 Jizan earthquake, that is located approximately $100 \mathrm{~km}$ to the south of the 2017 Namas earthquake, showed an oblique dip-slip movement along the NNE fault; revealing the second seismological evidence of reactivation over a strike-slip fault in Asir terrane that is attributed to the Pan-African fault systems (Greenwood et al. 1980). Accordingly, the stress accumulation of the large-scale tectonics of the Red Sea rifting system may be transferred across the transverse faults into the southernmost part of the eastern flank of the Red Sea.

Estimates of stress drops are influenced by many factors; i.e., source geometry, rupture directivity, rupture velocity, faulting styles, tectonic deformation rates, stress regime, rock composition, and focal depth (Kaneko and Shearer 2014; Goebel et al. 2015). Moreover, the variations in stress drops are attributed also to the source model assumptions (Huang et al. 2016). Some studies revealed comparable estimates of stress drop and other studies reported a varied range of estimates. The obtained stress drop value of $3.8 \mathrm{MPa}$ is not different from the stress drop of earthquakes in a crustal plateboundary, typical values of which are lower than $10 \mathrm{MPa}$ (Scholz 1990); implying a geodynamic process attributed to the Red Sea rift system and its conjugate strike-slip 
faults. Our estimates of stress drop are consistent with that estimated for the nearby earthquakes such as those which occurred in the south Red Sea, Afar region, Gulf of Aqaba, the Gulf of Suez and recently in Harrat Lunayyir, Saudi Arabia (Kebede and Kulhanek 1989; Pinar and Turkelli 1997; Hofstetter and Beyth 2003; Abdel Fattah et al. 2006; Allmann and Shearer 2009; Abdelfattah et al. 2019). On a global scale, our estimates of stress drops are consistent with the values estimated by Archuleta et al. (1982) for earthquakes of $\mathrm{Mw} \sim 4.0$. Estimates of stress drop for the 2017 earthquake sequence show a typical value similar to that reported for the shallow plateboundary earthquakes of tectonic origins.

The low friction coefficient of 0.3 implies a trigger of seismic activity in a weak fault zone. The low friction implies that the stress drop should also be low because high shear stress cannot be accumulated in such a medium, but there is no clear quantitative relation between low friction and stress drop. Moreover, the friction coefficient is a rather unstable parameter and an extensive dataset of accurate focal mechanisms is needed to obtain a more reliable value. It is noteworthy that the epicentral area geologically comprises gneissic granites and granodiorites. Gneiss shows strong foliation that forms as a result of shearing stress. Further shearing of the platy minerals like biotite along the foliation direction could lead to the reactivation of faults.

\section{Conclusions}

On the basis of the analysis of hypocenter relocations, focal mechanism solutions, and stress tensor inversion, in combination with the nearby fault trends, the fault plane oriented in the NE direction can be considered as the causative fault of the 2017 earthquake sequence. The contemporary shear stress regime exhibits a principal stress axis $\left(\sigma_{3}\right)$ having nearly shallow plunge horizontal with azimuth trending to the NW direction, indicating a rejuvenation of the pre-existing faults that are incompatible with large-scale regional tectonics of the Red Sea opening. The stress ratio of 0.16 reveals that the maximum and intermediate stresses are inclined with approximately similar magnitude. Estimates of stress-drops exhibited low values similar to those reported for shallow plate-boundary earthquakes in accordance with the low static friction. The accumulation mechanism of high shear stresses is unlikely to be accommodated in such a highly fracture zone that is associated with the extensional stress regime. Moreover, the low-stress drop values may imply a potential relation to the large-scale regional tectonics of the Red Sea opening that may be transferred into the respective terrane due to the pre-existing faults characterized by dextral shear deformations.

\section{Acknowledgements}

The authors would like to extend their sincere appreciation to the Deanship of Scientific Research at King Saud University for funding this Research group NO.(RG-1437-010). We are grateful to the Saudi Geological Survey (SGS) for providing the broadband seismic data. The software, Generic Mapping Tools developed by Wessel and Smith (1998), was used for some data mapping.

\section{Authors' contributions}

All authors carefully read and analyzed the manuscript before submitting. The author's AA and AA participated in focal mechanism inversion and estimated earthquake source parameters. SA participated in determining earthquake locations. MSS participated in writing a Matlab code to estimate the source parameters. FZ participated in writing the geological settings and discussions the results from geological and tectonic viewpoints. MF, SQ and NA participated in the analysis of earthquake location. AA and FZ prepared all maps. All authors actively participated in the interpretation and discussion of results. All authors read and approved the final manuscript.

\section{Funding}

This work was funded by the Deanship of Scientific Research at King Saud University for funding this Research group NO. (RG-1437-010).

\section{Availability of data and materials}

The datasets used and/or analyzed during the current study are available from the Saudi Geological Survey, Saudi Arabia.

\section{Competing interests}

The authors declare that they have no potential conflict or competing interests.

\section{Author details \\ ${ }^{1}$ Department of Geology \& Geophysics, King Saud University, Riyadh 11451, Kingdom of Saudi Arabia. ${ }^{2}$ Seismology Department, National Research Insti-} tute of Astronomy and Geophysics, Cairo, Egypt.

Received: 8 December 2019 Accepted: 26 February 2020

Published online: 11 March 2020

\section{References}

Abdel Fattah AK, Hussein HM, El Hady Sh (2006) Another look at the 1993 and 1995 Gulf of Aqaba earthquake from the analysis of teleseismic waveforms. Acta Geophys 54(3):260-279

Abdelfattah AK, Al-Amri A, Abdel el-aal AKH, Zaidi FK, Fnais M, Almadani S, Al-Arifi N (2017) The 23 January 2014 Jizan earthquake and its tectonic implications in southwestern Saudi Arabia. Tectonophysics 712-713:494-502

Abdelfattah AK, de Lorenzo S, Almadani S, Fnais M, Alfaifi H, Al-Arifi N (2019) Another look at the 2009 seismic activity, Harrat Lunayyir, Saudi Arabia. J Seismol 23:801-818

Abdel-Fatth AK, Morsy M, El-Hady Sh, Kim KY, Sami M (2008) Intrinsic and scattering attenuation in the crust of Abu-Dabbab area, eastern desert of Egypt. Phys Earth Planet Inter 168:103-122

Al Ganad I, Lagny P, Lescuyer J, Ramboz C, Touray J (1994) Jabali, a Zn-Pb-(Ag) carbonate-hosted deposit associated with Late Jurassic rifting in Yemen. Miner Depos 29(1):44-56

Aldamegh K, Sandvol E, Barazangi M (2005) Crustal structure of the Arabian plate: new constraints from the analysis of teleseismic receiver functions. Earth Planet Sci Lett 231(3):177-196

Aldamegh K, Abou Elenean K, Hussein H, Rodgers A (2009) Source mechanisms of the June 2004 Tabuk earthquake sequence, Eastern Red Sea margin, Kingdom of Saudi Arabia. J Seismol. 13:561-576

Aldamegh K, Hussein H, Al-Arifi N, Moustafa S, Moustafa M (2010) Focal mechanism of Badr earthquake, Saudi Arabia of August 27, 2009. Arab J Geosci 5(4):599-606

Allmann BP, Shearer PM (2009) Global variations of stress drop for moderate to large earthquakes. J Geophys Res Solid Earth 114(B1):B01310

Archuleta RJ, Cranswick E, Mueller C, Spudich P (1982) Source parameters of the 1980 Mammoth Lakes, California, earthquake sequence. J Geophys Res Solid Earth 87(B6):4595-4607 
ArRajehi A, McClusky S, Reilinger R, Daoud M, Alchalbi A, Ergintav S, Gomez F, Sholan J, Bou-Rabee F, Ogubazghi G, Haileab B (2010) Geodetic constraints on present-day motion of the Arabian Plate: implications for Red Sea and Gulf of Aden rifting. Tectonics 29(3):TC3011

Bamousa AO (2013) Infracambrian superimposed tectonics in the Late Proterozoic units of Mount Ablah area, southern Asir Terrane, Arabian Shield, Saudi Arabia. Arab J Geosci 6(6):2035-2044

Blasband B, White S, Brooijmans P, De Boorder H, Visser W (2000) Late Proterozoic extensional collapse in the Arabian-Nubian shield. J Geol Soc 157(3):615-628

Bokhari FY, Kramers JD (1981) Island arc character and late Precambrian age of volcanics at Wadi Shwas, Hijaz, Saudi Arabia: geochemical and Sr and Nd isotopic evidence. Earth Planet Sci Lett 54(3):409-422

Bosworth W (2015) Geological evolution of the Red Sea: historical background, re-view, and synthesis. The Red Sea. Springer, Berlin, pp 45-78

Brown GF, Jackson RO (1962) Geological map of the Asir Quadrangle, Kingdom of Saudi Arabia, United State Geological Survey. Misc. Geol. Inv. Map, pp $1-217$

Brune JN (1970) Tectonic stress and the spectra of seismic shear waves from earthquakes. J Geophys Res 75(26):4997-5009

Craig TJ, Jackson JA, Priestley K, Mc Kenzie D (2011) Earthquake distribution patterns in Africa: their relationship to variations in lithospheric and geological structure, and their rheological implications. Geophys J Int 185:403-434

de Lorenzo S, Zollo A, Zito G (2010) Source, attenuation, and site parameters of the 1997 Umbria-Marche seismic sequence from the inversion of $\mathrm{P}$ wave spectra: a comparison between constant QP and frequency-dependent QP models. J Geophys Res Solid Earth 115(B9):B09306

Endo E, Zahran H, Nofal H, Hadidy S (2007) The Saudi national seismic network. Seismol Res Lett 78(4):439-445

Fournier M, Huchon P, Khanbari K, Leroy S (2007) Segmentation and alongstrike asymmetry of the passive margin in Socotra, eastern Gulf of Aden: are they controlled by detachment faults? Geochem Geophys Geosyst 8(3):Q03007

Gettings ME (1983) A simple Bouguer gravity anomaly map of southwestern Saudi Arabia and an initial interpretation. Open File Rep. USGS-OF-03-94. U.S. Geol. Surv. Saudi Arabia Mission. Saudi Arabia Deputy Minist. for Miner. Resour., Jiddah (89 pp)

Goebel THW, Hauksson E, Shearer PM, Ampuero JP (2015) Stress-drop heterogeneity within tectonically complex regions: a case study of San Gorgonio Pass, southern California. GJI 202(1):514-528

Greenwood WR, Anderson RE, Fleck RJ, Roberts RJ (1980) Precambrian geology history and plate tectonic evolution of the Arabian shield. Saudi Arab Dir Gen Miner Resour Bull 24:1-35

Hamimi Z, El-Sawy ES, El-Fakharani A, Matsah M, Shujoon A, El-Shafei MK (2014) Neoproterozoic structural evolution of the NE-trending Ad-Damm shear zone, arabian shield, Saudi Arabia. J Afr Earth Sci 99:51-63

Hanks TC, Kanamori H (1979) A moment magnitude scale. J Geophys Res 84(5):2348-2350

Hargrove US, Stern RJ, Kimura JI, Manton WI, Johnson PR (2006) How juvenile is the Arabian-Nubian Shield? Evidence from Nd isotopes and pre-Neoproterozoic inherited zircon in the Bi'r Umq suture zone, Saudi Arabia. Earth Planet Sci Lett 252(3):308-326

Herrmann RB, Ammon CJ (2004) Computer programs in seismology. Manual of the Generic Seismic Application Coding (GSAC). Saint Louis University (Version 3.30)

Hofstetter R, Beyth M (2003) The Afar Depression: interpretation of the 1960-2000 earthquakes. Geophys J Int 155(2):715-732

Hokstad K, Mittet R, Landro M (1998) Elastic reverse time migration of marine walkaway vertical seismic profiling data. Geophysics 63(5):1685-1695

Huang Y, Beroza GC, Ellsworth WL (2016) Stress drop estimates of potentially induced earthquakes in the Guy-Greenbrier sequence. J Geophys Res Solid Earth 121(9):6597-6607

Ichinose G, Anderson J, Smith K, Zeng Y (2003) Source parameters of eastern California and western Nevada earthquake from regional moment tensor inversion. Bull Seismol Soc Am 93:61-84

Jansky J (2001) Ray-method Calculations of the Travel Times and Take-off Angles in Gradient Models, Program ANGGRA, Research Report. Dept. of Geophysics, Faculty of Math. and Phys., Charles University, Prague

Johnson PR (1998) Tectonic Map of Saudi Arabia and Adjacent Areas. Deputy Ministry for Mineral Resources, Saudi Arabia (USGS TR-98-3)
Johnson PR (2003) Post-amalgamation basins of the NE Arabian shield and implications for Neoproterozoic III tectonism in the northern East African orogen. Precambr Res 123(2-4):321-337

Johnson PR, Kattan FH (2001) Oblique sinistral transpression in the Arabian shield: the timing and kinematics of a Neoproterozoic suture zone. Precambr Res 107:117-138

Johnson PR, Woldehaimanot B (2003) Development of the Arabian-Nubian Shield: perspectives on accretion and deformation in the northern East African Orogen and the assembly of Gondwana. Geol Soc Lond Special Publ 206(1):289-325

Johnson PR, Kattan FH, Wooden JL (2001) Implications of SHRIMP and microstructural data on the age and kinematics of shearing in the Asir terrane, southern Arabian Shield, Saudi Arabia. Gondwana Res 4:172-173

Johnson PR, Andresen A, Collins AS, Fowler AR, Fritz H, Ghebreab W, Kusky T, Stern RJ (2011) Late Cryogenian-Ediacaran history of the Arabian-Nubian Shield: a review of depositional, plutonic, structural, and tectonic events in the closing stages of the northern East African Orogen. J Afr Earth Sci 61(3):167-232

Kaneko Y, Shearer PM (2014) Seismic source spectra and estimated stress drop derived from cohesive-zone models of circular subshear rupture. Geophys J Int 197(2):1002-1015

Kebede F, Kulhanek O (1989) Source parameters of selected earthquakes on the central and western margin of Afar. Tectonophysics 170:243-257

Keilis-Borok VI (1959) An estimation of the displacement in an earthquake source and of source dimensions. Ann Geofis 12:205-214

Madariaga R (1976) Dynamics of an expanding circular fault. Bull Seismol Soc Am 66(3):639-666

Makris J, Rihm R (1991) Shear-controlled evolution of the Red Sea: pull apart model. Tectonophysics 2-4:441-466

Mancilla P (2001) Surface wave dispersion about the Nw Madrid region. MSc thesis, Faculty of the Graduate School of Saint Louis University, USA

Nehlig P, Genna A, Asfirane F (2002) A review of the Pan-African evolution of the Arabian Shield. Geoarabia-manama 7:103-124

Pallister JS, Stacey JS, Fischer LB, Premo WR (1987) Arabian Shield ophiolites and Late Proterozoic microplate accretion. Geology 15(4):320-323

Pinar A, Turkelli N (1997) Source inversion of the 1993 and 1995 Gulf of Aqaba earthquakes. Tectonophysics 293:279-288

Rodgers AJ, Walter WR, Mellors RJ, Al-Amri AM, Zhang YS (1999) Lithospheric structure of the Arabian Shield and Platform from complete regional waveform modelling and surface wave group velocities. Geophys J Int 138(3):871-878

Ruff $L J$ (2002) State of stress within the earth. In: Lee WHK et al (eds) International handbook of earthquake \& engineering seismology (part A). Academic press, London, pp 539-558

Schmidt DL, Hadley DG, Stoeser DB (1979) Late Proterozoic crustal history of the Arabian Shield, southern Najd province, Kingdom of Saudi Arabia, evolution and mineralization of the Arabian-Nubian Shield. I.A.G. Bull 3(2):41-58

Scholz CH (1990) The mechanics of earthquake faulting. Cambridge University Press, Cambridge, pp 326-329

Schultz R, Mei S, Pană D, Stern V, Gu YJ, Kim A, Eaton D (2015) The Cardston earthquake swarm and hydraulic fracturing of the Exshaw Formation (Alberta Bakken play). Bull Seismol Soc Am 105(6):2871-2884

Skoumal RJ, Brudzinski MR, Currie BS (2015) Earthquakes induced by hydraulic fracturing in Poland Township, Ohio. Bull Seismol Soc Am 105(1):189-197

Stern RJ (1985) The Najd fault system, Saudi Arabia and Egypt: a late Precambrian rift-related transform system? Tectonics 4(5):497-511

Stern RJ, Johnson PR (2010) Continental lithosphere of the Arabian Plate: a geologic, petrologic and geophysical synthesis. Earth Sci Rev 101:29-67

Stoeser DB, Camp VE (1985) Pan-African microplate accretion of the Arabian Shield. Geol Soc Am Bull 96(7):817-826

Stoeser DB, Frost CD (2006) Nd, Pb, Sr, and O isotopic characterization of Saudi Arabian shield terranes. Chem Geol 226(3-4):63-188

Stoeser DB, Stacey JS (1988) Evolution, U-Pb geochronology and isotope geology of the 631 Panafrican Nabitah orogenic belt of the Saudi Arabian Shield. In: El-Gaby S, Greiling RO (eds) The Pan-African Belt of Northeast Africa and Adjacent 633 Areas. Vieweg, Braunschweig/Wiesbaden, pp 227-288

Suetsugu D (1998) Practice on source mechanism. IISEE Lecture Note, Tsukuba, p 104 
Tang T, Julià J, Zahran H, Mai PM (2016) The lithospheric shear-wave velocity structure of Saudi Arabia: young volcanism in an old shield. Tectonophysics 680:8-27

Tkalčić H, Pasyanos ME, Rodgers AJ, Gök R, Walter WR, Al-Amri A (2006) A multistep approach for joint modeling of surface wave dispersion and teleseismic receiver functions: Implications for lithospheric structure of the Arabian Peninsula. J Geophys Res Solid Earth 111(B11):B11311

Vavryćuk V (2011) Principal earthquakes: theory and observations from the 2008 West Bohemia swarm. Earth Planet Sci Lett 305:290-296

Vavryćuk V (2014) Iterative joint inversion for stress and fault orientations from focal mechanisms. GJl 199(1):69-77

Waldhauser F, Ellsworth WL (2000) A double-difference earthquake location algorithm: method and application to the northern Hayward fault, California. Bull Seismol Soc Am 90(6):1353-1368
Wessel P, Smith WH (1998) New, improved version of Generic Mapping Tools released. EOS Trans Am Geophys Union 79:579

Zeng Y, Anderson JG (1995) A method for direct computation of the differential seismogram with respect to the velocity change in a layered elastic solid. Bull Seismol Soc Am 85(1):300-307

\section{Publisher's Note}

Springer Nature remains neutral with regard to jurisdictional claims in published maps and institutional affiliations.

\section{Submit your manuscript to a SpringerOpen ${ }^{\odot}$ journal and benefit from:}

- Convenient online submission

- Rigorous peer review

- Open access: articles freely available online

- High visibility within the field

- Retaining the copyright to your article

Submit your next manuscript at $\boldsymbol{\nabla}$ springeropen.com 